Cadernos de Clio, Curitiba, n. ${ }^{\circ} 2,2011$

\title{
A Dinastia Tudor no romance histórico e no cinema: The Other Boleyn Girl
}

\author{
Stella Titotto Castanharo ${ }^{1}$
}

Resumo: O presente artigo é fruto da participação de um evento promovido pelo PET-História da UFPR no ano de 2010, denominado "Literatura e História na tela do cinema". O objetivo deste texto é estabelecer as principais relações entre romance histórico e produção cinematográfica, através de suas diferentes linguagens assim como pensar nas possíveis representações que a literatura e o cinema realizam acerca de uma temática histórica, no caso, a monarquia inglesa do século XVI.

Palavras chave: Modernidade- Dinastia Tudor, Romance Histórico, Cinema.

\section{Introdução}

Este artigo buscará estabelecer as relações entre romance histórico e produção cinematográfica, abordando as possíveis representações elaboradas por esses dois campos, assim como as problemáticas da adaptação de um romance histórico em relação à própria História e o cinema. Para tanto, nossos objetos de estudo

\footnotetext{
${ }^{1}$ Aluna da graduação em História na Universidade Federal do Paraná. É bolsista do grupo PET-História UFPR, no qual realiza a pesquisa individual "As faces do Rei: as diferentes representações historiográficas e audiovisual de Henrique VIII", sob orientação do Prof.Dr. José Roberto Braga Portella. Currículo lattes em: http://buscatextual.cnpq.br/buscatextual/visualizacv.jsp?id=K4475678Z7
} 
serão o livro The Other Boleyn Girl da escritora Philippa Gregory, e o filme The Other Boleyn Girl de Justin Chadwick. Esse estudo iniciará apresentando as informações técnicas de ambos os objetos.

\section{"The Other Boleyn Girl"- Informações técnicas do filme}

O filme "The Other Boleyn Girl de 2008 (título em português- A Outra) foi dirigido por Justin Chadwick (01/12/1968), diretor inglês mais afeito às produções televisivas, conhecido especialmente pela direção da série inglesa "Bleak house". "A Outra" é seu primeiro longa-metragem. O roteiro é de Peter Morgan que possui em seu currículo os filmes "Frost/ Nixon", "O último rei da Escócia", "A Rainha", além de ser o roteirista da série "O júri”. (http://www.imdb.com/title/tt0467200/, 2008)

Produzido por Alison Owen, também produtora de projetos como "Alice" (2010) e "Elizabeth" (1998), o filme foi realizado pela Universal Pictures Internacional, Columbia Pictures e BBC Films, evidenciando uma parceria estadunidense e inglesa. Esta parceria possibilitou aos dois países estabelecerem uma relação aproveitando a mesma língua, em que os EUA investem o dinheiro e escolhem grandes atores hollywoodianos para interpretar histórias que retratem a vida cotidiana ou até mesmo um período histórico da Inglaterra. Dessa forma, há um reforço da cultura e dos costumes ingleses, 
buscando enfatizar a nacionalidade, enquanto quase todo o retorno monetário fica para as empresas norte-americanas. A Inglaterra passa a ganhar também o direito de passar esses filmes na televisão, o que fica claro no filme "The Other Boleyn Girl" por ter o patrocínio da BBC. Desta forma, ambas saem lucrando no que haviam previsto.

Esta produção teve estréia mundial no Festival Internacional de Cinema de Berlim, em 15 de fevereiro de 2008, e alguns dias depois uma première em Londres. (http:// www.imdb.com/ title/ tt0467200/ releaseinfo, 2008) A partir desse momento, o filme foi sendo incorporado nas estréias cinematográficas de todo o mundo. Cabe destacar que a estréia americana se deu em 29 de fevereiro de 2008, enquanto na América Latina entrou em cartaz no mês de maio. Ao todo esta produção cinematográfica obteve mais de US \$ 65 milhões em vendas mundiais de ingressos, com um orçamento de US \$ 35 milhões até o ano de 2008. (http:// epipoca.uol.com.br/ filmes_bilheterias.php?idf $=19254,2008$ )

\section{- The Other Boleyn Girl-Resumo do filme}

O filme inicia apresentando a relação amistosa entre os três irmãos: Ana, George e Mary, quando crianças, ao mesmo tempo em que mostra os pais, Thomas e Elizabeth, discutindo sobre uma proposta de casamento para Ana. O patriarca da família decide casar 
Mary ao invés de Ana, porque acredita que esta é destinada a coisas muito maiores que um casamento com um mercador. A partir disso há um $t a k e^{2}$ para a festa de casamento de Mary Bolena. Ao mostrar a relação delas quando adultas evidencia-se o quanto as irmãs eram próximas e ao mesmo tempo disputavam o prestígio da família.

Após a festa de casamento Thomas dá à família a notícia de que o rei, Henrique VIII, irá visitá-los e que Ana terá a oportunidade de divertí-lo, tendo em vista que ele havia se decepcionado novamente com a rainha, Catarina de Aragão, por esta ter abortado mais uma gravidez. Nessa visita, Henrique VIII acaba por se machucar ao seguir Ana em uma cavalgada, o que permite que o monarca, nesse momento, conheça Mary.

Ao retornar à corte, Henrique VIII nomeia as duas irmãs como damas de companhia da rainha Catarina e o marido de Mary, Willian Carey, como Membro do Conselho Privado. Esta mudança já instaura um clima de tensão entre as irmãs, porque, para Ana, Mary estaria roubando seu lugar como amante do rei, e entre Mary e a rainha, pois esta também sabia o que Mary significava ao chegar à corte. Mary se torna a nova amante do rei. Ana se encanta ao pertencer à corte e passa a chamar atenção de todos os homens que

\footnotetext{
${ }^{2} \mathrm{O}$ take seria as mudanças de cenas nos filmes. Seriam algo como os parágrafos para o texto.
} 
Cadernos de Clio, Curitiba, n. ${ }^{\circ} 2,2011$

nela convivem, inclusive de Lorde Henry de Northumberland, enquanto Mary freqüenta os aposentos de Henrique.

Enquanto Mary e o rei têm um caso de amor, Ana foge para casar com lorde Northumberland. Ao descobrir isso, Mary conta a seu pai e tio, que convocam Ana e o Lorde para desfazerem o casamento deles, pois Northumberland era muito importante para se casar com alguém como $\mathrm{Ana}^{3}$. Por punição a esse comportamento Ana é enviada à corte francesa para aprender a se portar como uma dama e se retirar "de cena".

Mary engravida do rei o que lhe permite ser merecedora de mais e melhores presentes, como ter novos aposentos e obter titulação para seu pai e seu irmão. Mas ela acaba sofrendo complicações durante a gravidez, e se faz necessária outra garota para distrair Henrique. Sob vontade de Thomas, Ana é convidada a voltar para a corte inglesa. Nesse primeiro reencontro entre Ana e Henrique VIII se torna visível a todos da corte o quanto ela mudou, e o quanto seu temperamento e seu gênio estão acentuados. $O$ rei intrigado com este novo comportamento, passa a cortejá-la por não conseguir tirá-la de sua cabeça. Ana recusa todos os presentes que ele lhe oferece por não considerar correto que ele a corteje, enquanto

\footnotetext{
${ }^{3}$ Ana era considerada por seu tio e pai como alguém merecedora de um homem melhor que um mercador, mas não tão importante como Northumberland, o segundo homem mais rico da Inglaterra.
} 
espera um filho de Mary. Contudo, quando Mary dá à luz a um menino, Ana diz ao rei que aceita ser cortejada desde que ele não fale mais com sua irmã. Henrique concorda com tal condição.

Ana, por encargo da família, é obrigada a contar à sua irmã que esta voltará para o campo. Ao mesmo tempo, o rei tenta anular o seu casamento com Catarina, para que possa casar com Ana e finalmente ter um filho varão, tendo em vista que o filho de Mary era somente um bastardo. Ainda que o rei deseje consumar sua relação com ela, Ana afirma que só se entregará a ele quando este tiver se separado da rainha, pois assim o filho, fruto dessa relação, não seria considerado bastardo.

Mas o que não se esperava é que a então esposa do Lorde Northumberland, dissesse ao rei que ela não poderia permanecer casada, pois seu marido tinha um pré-contrato com Ana. Ou seja, tanto Ana quanto o lorde não podiam casar com outras pessoas, por já serem casados um com o outro. Mesmo que Ana tenha feito tudo para convencer o rei que não era verdade, ele dá ouvidos somente à Mary que acaba por confirmar a versão de que nunca havia tido um pré- contrato entre sua irmã e Northumberland.

Ao iniciar o processo de anulação de seu casamento, Henrique se irrita com o fato de Catarina não aceitar que eles não podiam ser casados, pois ela havia consumado seu primeiro 
casamento com o irmão de Henrique, Artur. Ao contar para Ana que a rainha não estava colaborando com a anulação, Ana sugere que o monarca não precisa da Igreja Católica para fazê-lo e sim que ele tem pleno poder de fazer isso como Chefe Supremo da Igreja da Inglaterra.

O rei fica irado com essa sugestão e com o fato de Ana não ceder às suas vontades, dessa forma ele acaba estuprando-a. Mas, ainda assim casa-se com ela, o que faz com que a aliança entre Inglaterra e a Igreja Católica seja rompida. Ana fica preocupada com o fato de não ser bem aceita pelo povo - afinal ela era vista sob o status de amante do rei -, mas se sente mais aliviada quando descobre que está grávida do rei, pois qualquer sugestão de que esse casamento não fosse legítimo cessaria.

Passado um tempo, Ana dá a luz à uma menina o que aumenta a ira do rei. Depois de um tempo ela engravida novamente, mas dessa vez aborta e chama Mary e George para ajudá-la. Preocupada com a sua situação, pede que George se deite com ela, pois o rei não o faria imaginando que ela estaria grávida. George não consegue fazê-lo, mas sua esposa diz ao rei que eles consumaram o ato.

Desta forma, Henrique leva Ana a julgamento por traição ao rei, bruxaria e adultério, juntamente com seu irmão. Ela é acusada e 
declarada culpada e tem por destino a decapitação. Ao descobrir isso, Mary tenta interceder por ela e recebe a promessa do rei de que sua irmã será enviada ao convento. Mas na hora de Ana receber o perdão real, Mary recebe uma carta do rei dizendo que ela não devia mais interceder ou interferir nas escolhas de Henrique. Ana seria morta como ele havia planejado.

Com a morte da irmã, Mary busca sua sobrinha, Elizabeth, e a tira da corte. Esta se tornaria rainha da Inglaterra por 45 anos e seu reinado ficaria conhecido como a Era Dourada da Inglaterra.

\section{"The Other Boleyn Girl" - Informações técnicas do romance}

Quanto ao livro, seu título no Brasil ficou como "A Irmã de Ana Bolena" ainda que o original seja "The Other Boleyn Girl", e ambos foram lançados no ano de 2002. Ele se tornou um Best-seller nos EUA e foi escrito por Phillipa Gregory (09/01/1954). A versão brasileira foi traduzida por Ana Luiza Borges pela Editora Record. Este livro ganhou o prêmio Parker Romantic Novel of the Year ${ }^{4}$ no ano em que foi editado e faz parte da coleção referente à Dinastia Tudor. A escritora inglesa possui doutorado na área de literatura do século XVIII pela Universidade de Edinburgh, além de ter livros

${ }^{4}$ Este prêmio é dado para autores ingleses que escrevem os melhores romances históricos ou modernos de cada ano. De 1986 a 2006 havia um prêmio em dinheiro para os autores. 
sobre a monarquia inglesa e corte inglesa dos séculos XV e XVI, e XVII e XVIII, respectivamente.

O livro é dividido em estações do ano, inicia na Primavera de 1521 e termina em Maio de 1536 (primavera). Isso representa a movimentação da corte Inglesa para cada um de seus castelos: Westminster- primavera, Windsor- verão e inverno, e Greenwichoutono, além, é claro, do Palácio de Hampton Court. Essa prática também era realizada para que a população visse o corpo físico de seu rei, porque dessa forma se compreendia o poder político exercido por ele. Era necessário visualizar o governante para que a lealdade e credibilidade desse governante fosse possível (VIGARELLO,2008). Os capítulos são divididos em subitens que permitem a leitura ágil e proporcionam um auxílio à adaptação cinematográfica, uma vez que proporcionam velocidade para história, considerando que são 15 anos em 626 páginas. Por ser um romance histórico, é indispensável se pensar que é criado um mundo ficcional em cima de um mundo real, o que torna necessário ao autor inserir seus personagens dentro do contexto em que irá retratar no livro. Isso é muito notável na obra de Gregory, porque, além de ter estudado por três anos a corte dos Tudors, ela usa como personagem principal alguém que é pouco retratada pela historiografia tradicional, tendo liberdade em sua criação. 
O narrador do livro é a própria Mary Bolena, que nos coloca na corte, junto à realeza inglesa, no jogo de sua família na tentativa de ascensão ao poder e, principalmente, em seus sentimentos como irmã de Ana Bolena, mulher, mãe e filha. Uma questão bastante esclarecedora e que vem a ser bastante curiosa é que durante toda a história elas dizem ser garotas Howard e não Bolena. Isso porque a mãe delas é Howard, o que as aproxima do temperamento dessa família e das suas constantes disputas para alcançar um status mais alto. Mas, ao mesmo tempo, Ana subverte isso ao reforçar sua identidade Bolena, ou seja, ela é filha de seu pai, portanto tem a astúcia, a inteligência e a fibra de um homem.

\section{- The Other Boleyn Girl-Resumo do livro}

Mary é casada com Willian Carey e ambos fazem parte da corte real. Após morte do tio de Mary Bolena que é acusado de traição, seu pai, Thomas Bolena, traz Ana, sua outra filha, para fazer parte da corte da rainha junto da irmã. Assim que Ana chega, o Cardeal Wolsey- braço direito do rei Henrique VIII- promove um baile de Carnaval em que cada uma das damas representa uma virtude.

A partir desse momento, o rei passa a cortejá-la, o que faz com que a família Howard e Bolena fique atenta a esse interesse 
repentino do monarca. George e Ana, seus irmãos mais velhos, são responsáveis por ensinar Mary a se relacionar com o rei, lembrando que Ana vinha da corte francesa, considerada a corte mais erudita, e George era amigo próximo do rei. Com essa ajuda, cada vez mais Henrique VIII se afeiçoava a Mary e ela a ele. Por sugestão de Ana, Mary é levada para o castelo da família em Hever para que o rei sinta saudades de Mary. Enquanto ela está afastada da corte e admirando o campo, Ana reforça o tempo todo as qualidades da irmã para o monarca.

Meses depois Mary retorna à corte e Henrique VIII a convida para os seus aposentos onde eles têm a sua primeira relação sexual. Mary passa, então, a ser oficialmente amante do rei. Ao mesmo tempo, Ana se relaciona às escondidas com Lorde Henry Percy de Northumberland, o homem mais rico da Inglaterra depois do rei. Então o Lorde e Ana se casam escondidos, mas têm seu casamento anulado logo em seguida, uma vez que ela não era da nobreza e por isso é retirada da vida na corte. No entanto, quando "as regras de Mary cessam", Ana é chamada de volta à corte para ajudála.

Após o parto, Mary volta à corte e sua filha fica sob cuidado de tutores. Ela engravida novamente do rei e durante esse processo o monarca demonstra cada vez mais sua insatisfação com a rainha por 
não gerar um filho homem. Mary acaba tendo complicações na gravidez e deixa a cargo de Ana seduzir e entreter o rei, para que ele não escolha outra mulher como amante. Finalmente, nasce um menino, Henrique. Mas, ao mesmo tempo, Ana passa a ser visivelmente cortejada pelo rei. Henrique VIII ainda fazia de Mary sua amante, mas conversava freqüentemente com Ana sobre filosofia e religião, pois ela era uma conselheira veraz para ele. Mary retorna para o campo e nesse tempo, Ana a informa de que o rei se casará com ela em um mês.

Ana sofre com a epidemia de suor maligno, o que a força a ir para o campo. Ao voltar recuperada para a corte, ela tem que reconquistar a atenção e amor do rei para si. Em 1529, inicia-se o julgamento contra a rainha Catarina com a acusação de não validade do casamento por esta não ter gerado um filho homem e também por Henrique considerá-la culpada acreditando que ela havia consumado seu casamento com o Príncipe Arthur e depois ter casado com Henrique.

Na primavera de 1531, Henrique torna-se chefe supremo da Igreja da Inglaterra, o que o torna autoridade máxima do estado e da religião, não precisando mais da permissão do Papa para anular seu casamento. Por fim, a rainha é abandonada enquanto Henrique passeia com a corte e sua amada Ana, mas o que eles não esperavam 
é que os súditos ingleses responderiam tão mal a essa nova rainha. Ela era mal vista, odiada pela população por ter tirado Henrique da rainha católica. Ao mesmo tempo, Mary é constantemente assediada pelo homem do campo Willian Stanfford. O rei dá à Ana o título de Marquesa de Pembroke e uma fortuna. Finalmente ela se entrega fisicamente ao rei.

Em uma viagem para a França, Ana não pode ir oficialmente como acompanhante do rei porque isso insultaria Francisco I de França. Em 1533, Ana é declarada esposa do rei da Inglaterra, de quem esperava um filho. No outono, nasce a princesa Elizabeth. Passado um tempo a rainha engravida, mas logo em seguida aborta e omite esse fato do rei, dizendo que cometeu um erro, pois não estaria grávida. Algum tempo depois Ana engravida novamente e pede que Mary volte para a corte. Dado que o bebê não se mexia em sua barriga, George e Mary procuram uma feiticeira para fazer o aborto. Ana engravida pela terceira vez consecutiva e mantém em segredo isso com George e Mary.

Em 1536, a rainha Catarina falece, o que dá esperanças à Ana de que será possível ter um filho varão de Henrique porque ela teria lutado contra tudo para concebê-lo. Ana conta para o rei de uma nova gravidez e ele decide fazer um torneio de justa para comemorar. Durante uma festa, Ana aborta na frente de todos. Quando retiram o 
nenê, percebem que ele é um monstro, o que levou à suspeita de que ela teria feito pacto com o diabo, e isso aumenta mais a raiva de Henrique. A garota Jane Seymour -dama da rainha- começa a ganhar grande prestígio, enquanto Ana é deixada de lado pelo rei, cada vez mais amargo. O soberano decide então que a rainha deve ser julgada por seus crimes.

Logo após, Ana é levada a julgamento acusada de traição, adultério e feitiçaria, assim como seus cortesãos, incluindo George. Ana é considerada culpada, e os demais também, mas o rei decide mandá-la para um convento, em razão da anulação do casamento. Em contrapartida, na manhã seguinte Henrique ainda muito descontente com a rainha muda sua pena. Dessa forma, Ana é encaminhada para o cadafalso e é decapitada. Mary e Willian, já com os três filhos, voltam para sua residência no campo. Tendo em vista que não podem fazer mais nada pela família Bolena, seguem adiante com suas vidas.

\section{Dialogando romance histórico com produção cinematográfica}

O primeiro ponto importante de diálogo é acerca de se pensar a respeito das traduções feitas tanto sobre o título do romance histórico como do filme. No título em inglês, tanto do livro quanto do filme, "The Other Boleyn Girl" reflete-se somente "a outra 
Bolena", expressão muito utilizada por ambas as Bolena durante todo o livro, enquanto elas revezavam a atenção do rei. Já, quando se muda para "A irmã de Ana Bolena", rapidamente se dá ênfase à própria Ana, o que não é visto no livro. Ao mesmo tempo, ao traduzir o título do filme para "A Outra" estabelece-se uma relação de alteridade que não é vista entre as personagens, além de ser um termo popular para designar a figura de um (a) amante.

É fundamental destacar o aspecto de fidelidade das adaptações de romances para o cinema. Robert Stam afirma que

\footnotetext{
"A noção de fidelidade ganha força persuasiva a partir do nosso entendimento de que: (a) algumas adaptações de fato não conseguem captar o que mais apreciamos nos romances- fonte; (b) algumas adaptações são realmente melhores do que outras; (c) algumas adaptações perdem pelo menos algumas das características manifestas em suas fontes." (STAM, 2008: 20)
}

Deve-se pensar que da mesma forma que há diferentes leituras de um mesmo romance também há diversas adaptações desse romance. Cabe lembrar também que a adaptação de livros para o cinema muitas vezes necessita de uma continuidade narrativa que permita ao espectador em pouco tempo acompanhar o enredo que se desenrola diante de seus olhos, enquanto que durante a leitura de um romance, o leitor tem mais tempo de envolvimento com personagens 
e trama. Isso é possível por conta de o cinema possuir uma relação de manipulação ao que consta os elementos de espaço e tempo. Por conta disso, é que se procura destacar elementos fundamentais para a compreensão da adaptação cinematográfica e do romance analisados.

Também se faz necessário compreender que Phillipa Gregory em sua obra apresenta diversas passagens envolvendo questões morais que não foram transpostas para o filme. Um exemplo interessante é quando Mary se envolve com o rei, pelo menos no livro, ela tinha 14 anos, o que não é retratado no filme. Isso porque em todo mundo as leis sobre relacionamento sexual de adultos e adolescentes ou crianças são bem diferentes. Hoje, por exemplo, na Inglaterra é permitido a relação sexual entre adultos e adolescentes acima de 16 anos. Por conta disso, é que se pode sugerir que o diretor Justin Chadwick, para resolver esse impasse, fez com que as duas personagens fossem representadas por mulheres com, aparentemente, mais de 20 anos.

Outro ponto interessante não tão destacado no filme é que, paralelamente às características humanistas da corte inglesa, é na corte francesa em que há erudição, cortesia, que as mulheres são mais instruídas, porque além de aprender línguas (Ana era fluente em três línguas naquela época) elas também aprendiam práticas de casa: como costura e bordado, preparo do corpo, entre outros. Ao mesmo 
tempo, o aspecto negativo, para o qual se pode atentar, é que as mulheres francesas eram conhecedoras de diversas formas de ter e de dar prazer na cama, o que poderia igualá-las ao status de prostitutas (FRASER, 2009: 164, 170).

Com relação à personagem de Mary, é possível notar a dicotomia constante entre campo e corte, em que as mulheres da corte eram consideradas ricas $\mathrm{e}$ as do campo pobres, não só materialmente, mas de espírito, de conhecimento. Mas, ao mesmo tempo, é possível perceber que, seja na corte ou no campo, a vida é muito feliz, as imagens são cheias de cores, de sabores, de cheiros, o que reflete o século XVI de forma muito positiva, apesar de momentos preocupantes como a epidemia de suor maligno.

Quanto às alianças ou negócios de família, é muito presente a ideia de que o casamento ou a proximidade com o rei levava a um aumento do status das famílias. Quando Mary começa a se envolver com o rei, ele não lhe dá somente presentes, ele eleva os cargos de seu pai, tio, irmão e marido, lhes dá cômodos nos castelos e dá títulos. Isso confirma, portanto, que ganhar a admiração do rei era a garantia de elevar a condição de toda a família. Fica bem claro que a relação entre uma das filhas e o rei torna-se assunto de família. Não há mais privacidade, pois tudo que acontece entre elas e ele deve ser revelado. 
Também é um elemento importante, a interferência contínua entre Estado e Igreja. Para que haja o favorecimento do rei ou das famílias ricas e aliadas a uma dessas instâncias, sempre se desfazem ou se fazem alianças que sejam melhores para os privilegiados. Esse é o caso da relação de Ana com Lorde de Northumberland, em que mesmo eles tendo afirmado a consumação do casamento, o Cardeal Wolsey diz à Ana que ele pode garantir a virgindade dela. Tudo isso para que um dos homens mais importantes da corte inglesa não se casasse com uma moça sem títulos.

Outro aspecto não abordado pelo filme é a questão de sodomia e homossexualidade vivida por George Bolena. A sodomia era considerada pecado capital e qualquer homem que fosse culpado por esta prática era considerado traidor e condenado à morte. Essa prática continuou sendo crime até o início do século XIX na Inglaterra. $O$ sujeito que a cometesse deixava a família numa situação delicada, a qual poderia ser expulso da corte pelo rei. Seja pela sodomia ou homossexualidade de George, Ana reforça, no livro, que ele deveria parar com essas "bizarrices" 5 antes que a prejudicasse. Independente disso, no romance ele é acusado de sodomia com três cortesãos, além de homossexualismo, e suspeito de incesto com a rainha. Ou seja, a figura de George é de muita

\footnotetext{
${ }^{5}$ Este termo foi utilizado na tradução do livro.
} 
polêmica e a utilização dessas circunstâncias poderia favorecer tanto a alegação que a Inglaterra do século XVI era extremamente preconceituosa, e este preconceito não aconteceria hoje; como, ao mesmo tempo, poderia levar a sérios problemas para a produção cinematográfica como a defesa da morte de homossexuais. Independente do uso que fosse feito desse elemento, o foco acabaria saindo da intenção de Chadwick que era mostrar a relação de disputa entre duas irmãs pelo amor de um rei, pois destacaria questões polêmicas que não eram sua proposta para o longa.

Incesto é outro ponto que, embora no filme seja negado, no livro quase se tem certeza que aconteceu. Observa-se isso após o $3 .^{\circ}$ aborto de Ana em que ela tem um diálogo com o irmão dizendo que achava que ele nunca mais iria tocá-la por ficar com medo dela. Além do que, ao longo de todo o livro, há uma sugestão de uma tensão sexual entre os dois, porque ele a beija de boca aberta e em alguns episódios a vê nua. Afinal, sendo integrantes da mesma família, isto era considerado inadequado. Também poderia se sugerir que o medo de George se daria por perceber o quanto uma relação amorosa com a irmã poderia gerar um monstro e que isso além de inaceitável, era pecado diante dos olhos de Deus. ${ }^{6}$

\footnotetext{
${ }^{6} \mathrm{O}$ resultado de uma relação monstruosa se dá pelo fato que a mistura genética se torna menor, porque pessoas próximas, como irmãos, têm genes muito parecidos e
} 
Dessa forma não se pode afirmar com veemência sobre a questão da sexualidade de George Bolena ou a questão do incesto que envolveu George e Ana. Não há nada na historiografia que permita esse tipo de afirmação, muito menos foram encontradas fontes sobre o tema. Mas a maior parte dos historiadores acredita na inocência dos irmãos e na heterossexualidade de George porque há documentos que o colocam como um grande sedutor de mulheres. Agora a prática da cortesania é constantemente destacada pela historiografia, seja através de manuais ou na própria construção da identidade da corte.

Uma crítica que pode ser pertinente ao filme é que ele trata a mãe das Bolena com valores do século XX e XXI, pois mostra a preocupação dela com as filhas, com a sua criação. Por outro lado o que é mostrado no livro é justamente a frieza dela enquanto mãe, a qual só foi considerada como tal porque deu à luz aos três filhos. Ela não os cria, quem cria são tutores nas cortes que ensinam tudo que eles precisam para serem bons cortesãos. A mãe dos Bolena também foi conduzida nesse jogo de alianças familiares e sabe que seus filhos não serão desviados disso. Ela vive de acordo com o seu lugar de esposa de Thomas Bolena e súdita do rei Henrique VIII.

ao realizar uma mistura tão próxima os genes acabam não possuindo uma variabilidade genética, produzindo seres com deformações. 
O que também é muito pertinente destacar é que, apesar de Phillipa Gregory ter estudado cerca de três anos a corte dos Tudors, ainda assim há algumas irregularidades históricas. A primeira delas seria a própria idade dos filhos Bolena: no livro George é o primogênito, no entanto a historiografia apresenta a própria Mary como a mais velha. Ainda em relação às relações familiares, outro fator questionável é o caso dos filhos de Mary serem frutos de uma relação com rei. Isso porque até mesmo os filhos bastardos de Henrique VIII foram creditados como seus, o que não ocorreu no caso dos filhos de Mary, o que sugere à grande parte dos historiadores que esses filhos não teriam sido do monarca.

\section{Representação: o diálogo entre romance histórico, produção cinematográfica e História}

Nesta etapa do artigo será discutida as diferentes representações dos personagens que mais obtiveram destaque na obra de Phillipa Gregory. São eles: Henrique VIII, Catarina de Aragão, Ana Bolena e Mary Bolena. Procura-se perceber como literatura e cinema dialogam com os elementos apresentados pela historiografia.

Henrique VIII (1491-1547): tradicionalmente, pela historiografia, a imagem que se tem do monarca Tudor é a de um homem 
velho, rechonchudo e perverso ${ }^{7}$. Afinal, teve seis esposas, de duas divorciou-se e matou outras duas. Na obra de Phillipa Gregory, essa representação não ocorre assim. Ele é o jovem de corpo atlético, dos cabelos dourados cor de mel, dos olhos azuis, um excelente jogador, mas acima de tudo um sedutor e conquistador. Como cortesão ideal, além de monarca completo, ele conquistava todas as mulheres que estavam ao seu redor.

Isso é destacável, porque a historiografia voltada à história dos corpos defende a ideia de que era a partir do corpo do rei e de sua etiqueta que a monarquia era composta, afinal, era através dos rituais exercidos pelo rei e por sua corte que se constituía uma dinastia. Henrique VIII precisava ser um homem quase idealizado, pois o corpo dele representava $o$ poder da Inglaterra. Tradicionalmente, na história da Inglaterra o corpo do rei não representava somente o corpo físico, mas também o corpo político do estado. Porque o status da figura real é imortal, o REI nunca morre, morre somente o corpo físico do homem que governa. Para tanto, o corpo político do rei é definido por seus súditos que juntos formam um corpo-nação, e que está posto ali para governar. Esse corpo diferente do corpo físico do rei não sofre com humores, paixões,

\footnotetext{
${ }^{7}$ André Maurois o classifica como: "um grande príncipe da Renascença é libertino, culto, magnífico e muitas vezes cruel". (MAUROIS, 1960: 241) Ou seja, mesmo apresentando características positivas, a imagem que permanece desse rei é a de crueldade e de libertinagem nos seus relacionamentos.
} 
desejos, se torna um corpo intocável e imaculado. A partir desses dois corpos, físico e político, e pelo exercício das cerimônias do Estado $^{8}$ em relação ao poder é que se torna possível a representação do Estado por apoio divino (VIGARELLO, 2008: 506-515).

Dificilmente, essa representação idealizada aparece no cinema ou em outras literaturas. Quando novo ele é apresentado com esse aspecto ranzinza, rancoroso e sombrio. Apesar de a primeira aparição de Henrique VIII no livro ser na execução de um lorde, é importante pensar que ele estava realizando seu poder de monarca, afinal também há demonstração de doçura por parte dele com seus filhos e suas amantes. O rei encantava as mulheres, não só pela beleza, mas também por sua incrível capacidade de fazê-las se sentir únicas no mundo.

Interessante destacar que sua frieza e tristeza só começam a aparecer no livro quando Henrique percebe que se torna cada vez mais difícil deixar um herdeiro homem para reinar sobre a Inglaterra. Isto porque, estava muito presente na memória inglesa o fato de que tinha sido seu pai (Henrique VII) que fizera ter fim a guerra civil inglesa (Guerra das Duas Rosas) ${ }^{9}$ pela busca de quem deveria ser o

\footnotetext{
${ }^{8}$ Essas cerimônias vão desde a rotina física do rei, de alimentar-se, até mesmo a reuniões com embaixadores.

${ }^{9}$ A Guerra das Duas Rosas foi uma disputa dinástica entre Lancaster e York para assumir o trono inglês. Henrique VII esposo de Elizabeth de York venceu a guerra,
} 
rei da Inglaterra. Depois de anos de luta pela conquista do trono e de consolidação da Inglaterra por Henrique VII, Henrique VIII percebia que cada vez mais suas chances de produzir um filho varão, para manter a estabilidade da Inglaterra, tornavam-se menores. Pois a Inglaterra não teria forças pra disputar uma nova batalha dinástica e ao mesmo tempo disputar poder com suas inimigas França, de Francisco I, e Espanha, de Carlos V. O que historicamente não foi confirmado porque, apesar de não ter tido um filho varão que desse continuidade ao seu poder, Henrique VIII foi pai de uma das rainhas mais importantes da Inglaterra, Elizabeth.

Catarina de Aragão (1485- 1536): talvez a personagem mais respeitada por Mary, não era da realeza somente por casamento. Ela era uma princesa real, era filha de Isabel e Fernando, reis de Castela e Aragão, que lutaram bravamente contra a invasão moura. Os reis católicos fizeram de suas filhas, em especial Catarina, grandes mulheres eruditas destinadas a se casarem com grandes homens e serem mulheres de fibra. Considerada uma espanhola muito bela ${ }^{10}$ (FRASER, 2009: 37), sempre foi lembrada por sua serenidade e

instaurando a dinastia Tudor no poder. A guerra civil foi de 1455 a 1485,30 anos de muitas mortes e destruição da Inglaterra.

${ }^{10}$ Deve-se pensar que o padrão de beleza da época era caracterizado através: da pele branca indicando a pureza, os cabelos claros, e o corpo mais encorpado, tendo em vista que mulheres mais "rechonchudas" tenderiam a indicar fertilidade e saúde. Segundo as cartas de diferentes embaixadores da corte inglesa, Catarina correspondia perfeitamente a estas características. 
capacidade de confortar o rei. Dificilmente o ofendia ou às suas damas, como aparece no filme, que, por sinal, diminuiu-lhe a uma posição quase insignificante. Considerada, pelos embaixadores de sua corte (e posteriormente por historiadores) profundamente casta, não abalou sua fé por um instante qualquer diante da vontade do marido em anular seu casamento, ou em não ter um filho varão. Rezava constantemente para receber essa graça e, como uma bela dama, mantinha-se no seu lugar de esposa e não se preocupava com as escapadas de Henrique, pois ele sempre voltava para ela. Amada por sua cordialidade e generosidade, $o$ povo a considerava praticamente como uma mãe para todos. Phillipa Gregory destaca que a possibilidade de o rei abandonar uma mulher fiel e honesta por capricho deixava as esposas inglesas preocupadas, assim, nenhuma estava segura em seu casamento.

Ana Bolena (1501(?) - 1536) e Mary Bolena: a mulher mais interessante e mais forte de todo o período Tudor e a única que se colocava como igual perante o rei: Ana foi mãe da rainha Elizabeth e, embora não tenha dado o filho varão que o rei tanto queria, deu-lhe uma das monarcas mais importantes da realeza inglesa. 
Ana Bolena esteve na corte francesa dos três aos 15 anos aproximadamente $^{11}$, extremamente erudita em línguas, filosofia e interessada nos estudos religiosos, não se colocava como um "peão" dentro da família Howard, mas sim como a "torre", pronta pra dar um "cheque-mate" no rei. Não se colocou na posição de mulher submissa, pelo contrário, por seu gênio forte e pela sua erudição alcançou tudo o que sempre almejou, antes mesmo de se entregar para o rei. Sempre referenciada como uma das mais belas mulheres da corte Tudor, nunca era deixada de lado, pelo contrário, sempre era o centro das atenções. Além de esposa e confidente do rei Henrique, foi importante no momento de rompimento com a Igreja Católica e surgimento do Anglicanismo. Ainda que tenha procurado fazer seu próprio destino casando-se com Henry Percy de Northumberland, foi com o rei que se tornou uma das mulheres mais importantes de seu tempo.

Em contrapartida, Mary Bolena, apesar de também ter ido para a corte inglesa dos três aos 12 anos $^{12}$, se casou aos 13 anos com lorde Willian Carey buscando as alianças entre famílias e, da mesma forma, buscando se colocar dentro da corte inglesa. Ao ser querida

\footnotetext{
${ }^{11}$ Por não ser nobre o ano exato de seu nascimento causa controvérsias, lembrando que os nobres datavam os nascimentos.

${ }^{12}$ A questão da idade também se aplica a Mary Bolena, através de poucas fontes encontradas é que se procura realizar uma média da idade que ela poderia ter nesses momentos.
} 
pelo rei inglês, Mary representa, fundamentalmente, aquelas mulheres que deveriam seguir as ordens das famílias de representar seu papel. Apesar de ser uma amante da corte, ao se envolver com a experiência da maternidade, subverte a ordem da nobreza ou alta burguesia ao querer ensinar seus próprios filhos. Mas não se sabe se de fato ela foi amante do rei, e se seus filhos poderiam ter sido dele, mas é nessa personagem que há o conflito primordial entre a vida no campo e na corte, o amor e jogo.

O relacionamento entre as duas irmãs promovido por Phillipa Gregory se dá, especialmente, pela relação de amor e ódio que havia entre elas. Ao mesmo tempo em que precisavam se ajudar para manter seu status, disputavam a atenção de sua própria família e de seus pretendentes. Juntas eram impossíveis, separadas tentavam da forma que fosse possível encontrar a felicidade, ainda que para isso fosse necessário jogar com as peças do jogo. Outro fato interessante é que, durante toda a narrativa do livro, Ana reforça o quanto as duas irmãs exerceram o papel de prostituta para ganharem o prestígio do rei, e que ela conseguiu subverter essa ordem ao se tornar rainha. 


\section{Considerações finais}

Para concluir, é importante pensar que um escritor sempre escreve o livro e o roteirista sempre escreve o roteiro do filme, portanto, o filme além de ser uma interpretação e leitura do roteirista, é uma adaptação do livro. Logo, jamais será uma história transposta na íntegra do livro para o filme. Ela é adaptada, especialmente, pela linguagem e pelos artifícios que o roteirista considera que tornam o filme mais compreensível e dinâmico para o público. A ideia central da história se manteve, de modo a mostrar a corte inglesa durante o difícil período que foi a Inglaterra ao longo do processo de anulação do casamento do rei Henrique VIII e da rainha Catarina de Aragão. Mas, mais do que isso, a intenção é mostrar que, por trás de toda a nobreza, realeza e suas práticas políticas, todos possuíam sua subjetividade, sentimentos, vontades e necessidades. Sentiam seus medos, suas frustrações e tinham a imensa necessidade de viver de acordo com as normas e com o que era esperado dentro dos valores do século XVI. Não se pode, jamais, tentar inserir os valores do século XXI ou até mesmo a forma de pensar contemporânea dentro de uma história que se passa há cinco séculos. O que sempre foi considerado o maior pecado do historiador, também deve ser constantemente ressaltado por escritores e roteiristas que trabalham 
com histórias de períodos anteriores, ainda mais, nesse caso, que é a história de um monarca tão importante para a realeza inglesa.

Mesmo apresentando alguns tradicionais problemas na literatura como colocar a mulher como manipuladora; e sempre ser a mulher morena a má e a loira a boa, assim como fazer do homem um simples boneco na mão de ambas as mulheres, deve-se pensar que não eram elas que manipulavam sozinhas e sim que suas famílias estavam por trás disso e que o próprio rei tinha conhecimento destas práticas das famílias cortesãs para a ascensão social e aumento de posses. Apesar disso, o filme mostra cenários e figurinos muito verossímeis, assim como uma fotografia e trilha sonora muito bem elaboradas e pertinentes para o tema. Acredita-se que apesar dos problemas recorrentes acima ditos a intenção do filme e seu resultado foi muito bom, pois ele realmente conseguiu mostrar a complexa relação de amor entre duas irmãs e um dos reis mais importantes do século XVI. Portanto, com exceção dos problemas acima citados, "a análise das representações tem importância porque o cinema pode levar as platéias que não estão familiarizadas com os fatos e características de determinada sociedade a acreditarem em uma versão distorcida ou estereotipada." (DE FAZIO, 2009: 297). E isso é bem presente no filme analisado porque retrata uma parte da história inglesa sob pontos de vista diferentes do período abordado. 
Quanto ao livro, apesar de também ser necessário fazer algumas ressalvas, fica muito presente que a parte histórica da trama serviu como pretexto para se escrever sobre amor, disputa, traição e romance no século XVI. Ambos os materiais reforçam a ideia de que a intenção não era fazer uma obra historiográfica, no caso do livro, ou um documentário, no caso do filme, sobre o que foi a monarquia inglesa do século XVI, mas, sim, mostrar que sob este pano de fundo há a possibilidade de falar desses outros tantos temas que normalmente são o que levam o grande público aos cinemas e as livrarias.

\section{Referências Bibliográficas}

GREGORY, Philippa. A irmã de Ana Bolena. Rio de Janeiro- São Paulo: Editora Record, 2010.

A Outra. 2008. Direção de Justin Chadwick. Realização Universal Pictures Internacional, Columbia Pictures e BBC Films http://en.wikipedia.org/wiki/The_Other_Boleyn_Girl acessado em 20 de agosto de 2010 . http://www.sonypictures.com/homevideo/theotherboleyngirl/index.ht $\mathrm{ml}$ acessado em 20 de agosto de 2010. http://www.philippagregory.com/ acessado em 20 de agosto de 2010. 
http://home.comcast.net/ antaylor1/parkerromance.html acessado em 20 de agosto de 2010.

http://www.imdb.com/name/nm0149491/ acessado em 20 de agosto de 2010.

http://www.imdb.com/title/tt0467200/releaseinfo acessado em 20 de agosto de 2010.

http://epipoca.uol.com.br/filmes_bilheterias.php?idf=19254 acessado em 20 de agosto de 2010.

CATERER, James. HIGSON, Andrew. "A Indústria cinematográfica britânica." In: MELEIRO, Alessandra (org.) Cinema no mundoIndústria, politica e mercado. Volume V- Europa. São Paulo: Escrituras Editora, 2007.

DE FAZIO, Andréa Helena Puydinger. Crítica à imagem eurocêntrica: uma reflexão acerca das representações étnicas e culturais em Hollywood. In: Anais II Encontro Nacional de Estudos de Imagens. Londrina, maio de 2009.

FERRO, Marc. Cinema e História. Rio de Janeiro: Paz e Terra, 1992.

FRASER, Antonia. As seis Mulheres de Henrique VIII. Rio de Janeiro: Bestbolso, 2009. 
FREIRE, Flávio. ZANINELLI, Renata. Literatura e adaptação cinematográfica: diferentes linguagens, diferentes leituras. In: SOLETRAS, Ano VIII, n. ${ }^{\circ}$ 15. São Gonçalo: UERJ, jan./jun.2008.

MAESTRI, Mário. História e romance histórico: fronteiras. In: Novos Rumos, Ano 38, n. ${ }^{\circ}$ 36, 2002.

MAUROIS, André. História da Inglaterra. Lisboa- São Paulo: Editora Aster e Editora Flamboyant, 1960.

ROSENSTONE, Robert A. A História nos filmes, Os Filmes na História. São Paulo: Paz e Terra, 2010.

STAM, Robert. A Literatura através do cinema: Realismo, magia e a arte da adaptação. Belo Horizonte: Editora UFMG, 2008. VIGARELLO, Georges. In: CORBIN, Alain; COURTINE, JeanJacques; VIGARELLO, Georges. História do Corpo: da Renascença às Luzes. Petrópolis: Editora Vozes, 2008. "O Corpo do Rei" 